\title{
ANALISIS PENGARUH TRI HITA KARANA TERHADAP PENGELOLAAN KEUANGAN DESA DI DESA ANTURAN
}

\author{
Kadek Yunira Sedani, Ni Komang Sukartini, Ketut Juni Budiasih, Luh Putu \\ Windiani, Ni Made Yudiani, Komang Tri Pebrianti Laksmi \\ Jurusan Akuntansi, Universitas Pendidikan Ganesha, Singaraja, Bali, Indonesia
}

\begin{abstract}
Abstrak
Penelitian ini bertujuan untuk mengungkap bagaimana pengelolaan Keuangan Desa di Desa Anturan, bagaimana alokasi dana untuk kegiatan yang berkaitan dengan prahyangan, bagaimana alokasi dana untuk kegiatan yang berkaitan dengan Pawongan, bagaimana alokasi dana untuk kegiatan yang berkaitan dengan palemahan serta bagaimana Konsep Tri Hita Karana diterapkan dalam Pengelolaan Keuangan Desa. Pengumpulan data dilakukan melalui teknik wawancara dan dokumentasi. Hasil penelitian menunjukkan bahwa terdapat pengaruh Tri Hita Karana dalam pengelolaan keuangan desa di desa Anturan dimana dibuktikan dengan kegiatan-kegiatan yang telah dilaksanakan oleh pengurus desa yang mencerminkan hubungan manusia denganTuhan (prahyangan), manusia dengan manusia (pawongan), manusia dengan lingkungan (palemahan), seperti kegiatan fasilitasi pelaksanaan upacara keagamaan,kegiatan oprasional perbekel dalam rangka kegiatan sosial masyarakat, kegiatan pemeliharaan balai banjar. Adapun alokasi dana yang berhubungan dengan prahayangan yaitu $15 \%$, palemahan $70 \%$ dan pawongan $15 \%$.
\end{abstract}

Kata kunci: Tri Hita Karana; pengelolaan keuangan desa; desa Anturan

\begin{abstract}
This study aims to reveal how to manage Village Finances in Anturan Village, how to allocate funds for activities related to prahyangan, how to allocate funds for activities related to Pawongan, how to allocate funds for activities related to poverty and how the Tri Hita Karana Concept is applied in Village Financial Management. Data collection is done through interview and documentation techniques. The results showed that there was an influence of Tri Hita Karana in village financial management in the village of Anturan where evidenced by activities that have been carried out by village administrators that reflect the human relationship with God (prahyangan), humans with humans (pawongan), humans with the environment (palemahan), such as facilitation activities of religious ceremonies, operational activities of the bureau in the context of social activities, maintenance of the banjar hall. The allocation of funds related to prahayangan is 15\%, $70 \%$ weakening and pawongan $15 \%$.
\end{abstract}

Keyword: Tri Hita Karana; village financial management; Anturan village

\section{Pendahuluan}

Menurut Undang-Undang Nomor 23 Tahun 2014 Tentang Pemerintah Daerah, "Desa adalah kesatuan masyarakat hukum yang memiliki batas wilayah yang berwenang untuk mengatur dan mengurus urusan pemerintahan, kepentingan masyarakat setempat berdasarkan prakarsa masyarakat, hak asal usul, dan/atau hak tradisional yang diakui dan dihormati dalam sistem pemerintahan Negara Kesatuan Republik Indonesia". Secar admnistratif desa merupakan bentuk pemerinahan terkecil yang dipimpin oleh kepala desa. Dalam menjalankan suatu pemerithan di desa ,kepala desa dibantu oleh staf-staf desanya. Staf -staf desa ini menjalankan pekerjaannya sesuai dengan jabatan masing-masing.

Pemerintah berusaha mengatur,mengurus urusan pemerintah dan kepentingan masyarakat setempat ,tentunya dalam halini di perlukan dana agar dapat mencapai tujuan dan mensejahterakan desa. Salah satusumber dana yang dimilikioleh desa adalah alokasi dana desa (ADD).

Menurut Undang-Undang Nomor 6 Tahun 2014 Tentang Desa menyatakan bahwa “ Alokasi Dana Desa paling sedikit 10\% dari dana perimbangan yang diterima Kabupaten/Kota dalam Anggaran Pendapatan dan Belanja Daerah setelah dikurangi Dana Alokasi Khusus. Penggunaan Anggaran Alokasi dana Desa adalah sebesar 30\% (tiga puluh persen) untuk 
belanja aparatur dan operasional pemerintahan desa, sebesar 70\% (tujuh puluh persen) untuk biaya pemberdayaan masyarakat". Dengan diterimanya dana bagi desa tersebut, pemerintahan desa harus siap dan mampu dalam mengelola keuangan desa berdasarkan asas transparan, akuntabel, partisipasif serta dilakukan dengan tertib dan disiplin anggaran sesuai dengan Permendagri No. 37 tahun 2007 Tentang Pedoman Pengelolaan Keuangan Desa. Keuangan desa tersebut dikelola melalui kegiatan yang meliputi perencanaan, penganggaran, penatausahaan, pelaporan, pertanggungjawaban dan pengawasan keuangan desa yang dilakukan oleh Kepala Desa yang dibantu oleh Pelaksana Teknis Pengelolaan Keuangan Desa (PTPKD).

Pemerintah desa juga berusaha untuk menunjukkan transparasi dan akuntabilitasnya kepada masyarakat untuk melakukan Pengelolaan Keuangan desa yang baik dan benar sesuai dengan Peraturan Menteri Dalam Negeri Nomor 37 Tahun 2007 mengenai Pedoman Pengelolaan Keuangan. Dengan hal ini masyarakat akhirnya dapat menilai kinerja pemerintah desa secara langsung, jika kinerja pemerintah desa baik maka masyarakat akan memberikan apresiasi yang baik, namun apabila hasil pengelolaan keuangan desa tidak diungkapkan kepada masyarakat maka pengelolaan keuangan desa tidak dapat diketahui oleh masyarakat sehingga pemerintah desa belum menunjukkan transparansi dan akuntabilitasnya pada masyarakat umum (Riza Ramadhan, 2014:3).

Adanya tahapan-tahapan pengelolaan keuangan desa yang telah tertuang di Permendagri No. 37 Tahun 2007, peneliti tertarik meneliti perencanaan keuangan desa. Perencanaan keuangan desa merupakan point pertama yang ada di pengelolaan keuangan desa dan juga merupakan tahapan awal atau merupakan langkah awal dari pengelolaan keuangan tersebut. Perencanaan ini dilaksanakan dalambentuk penyusunan Anggaran Pendapatan dan Belanja Desa (APBDes), yang berasal dari proses penyusunan Rencana Kerja Pemerintah Desa (RKPDesa) yang dihasilkan dari proses Musrenbang desa dengan berpatokan pada Rencana Pembangunan Jangka Menengah Desa (RPJMDesa). Dipilihnya perencanaan keuangan desa karena peneliti ingin menganalisa bagaimana desa dapat merancang penyusunan APBDesa yang baik dan benar juga berperan penting sebagai alat pengawasan dan pengendalian kegiatan pengelolaan keuangan desa.

Adapun faktor yang sangat mendasar yang mempengaruhi perencaan ,pengolahan ,pelaksanaan dan pertanggung jawaban terkait penggunaan Alokasi Dana Desa (ADD) adalah budaya dari masing-masing desa itu sendiri.

Bali adalah salah satu provinsi di Indonesia yang sangat terkenal kental dengan budaya adat dan istiadat. Salah satu tradisi yang cukup terknal dalam masyarakat Bali adalah konsep Tri Hita Karana. Tri Hita Karana adalah kearifan lokal (lokal wisdom) yang sudah menjadi kepribadian budaya (cultural identity) karena mampu mengakomodasikan dan mengintegrasikan unsur-unsur budaya luar ke dalam kebudayaan asli sekaligus menjadi bingkai tatanan kehidupan masyarakat Bali di berbagai sektor .Tri Hita Karana adalah konsep bersifat totalitas meliputi alam semesta, di mana unsur-unsur Tri Hita Karana di alam semesta (makrocosmos) meliputi Lingkungan alam fisik, manusia sebagai penggerak alam, dan Tuhan yang menjiwai alam semesta .

Pada dasarnya dapat diukur Tri Hita Karana yang menekankan bahwa kesejahteraan dicapai bila terealisasi hubungan harmonis antara manusia dengan Tuhan (parhyangan), dengan sesama manusia (pawongan) dan alam lingkungan (palemahan) .Untuk lebih jelasnya maka akan dijelaskan secara sepesifik terkait perspektif Tri Hita Krana itu sendiri sebagai berikut.

Presfektif parhayangan, (sraddha) dan ketakwaan (bhakti) kepada Tuhan. Keimanan dalam hal ini berarti keyakinan akan keberadaan Tuhan sebagai pencipta, pemelihara dan pelubur alam semesta beserta isinya. Sedangkan bhakti artinya sujud dan cinta pada Tuhan.

Perspektif pawongan dalam budaya Tri Hita Karana perlu terciptanya dan atau dijaga hubungan yang harmonis antara manusia dengan stakeholder-nya dalam situasi di kantor, desa pakraman, pemerintah dan lingkungan sosial

Perspektif palemahan Perusahaan harus menyelaraskan tanggung jawab ekonomi dengan tanggung jawab sosial dan lingkungan. Untuk melihat keterkaitanya maka peneliti tertarik untuk melihat implemntasi penerapaan Tri Hita Karana terhadap rencana 
pengelolaan dana desa, maka dari itu peneliti akan melakukan "Analisis Pengaruh Tri Hita Karana Terhadap Pengelolaan Keuangan Desa di Desa Anturan"

Berdasarkan penjelasan di atas, maka dapat dirumuskan beberapa masalah yaitu bagaimana pengelolaan Keuangan Desa di Desa Anturan, bagaimana alokasi dana untuk kegiatan yang berkaitan dengan prahyangan, bagaimana alokasi dana untuk kegiatan yang berkaitan dengan Pawongan, bagaimana alokasi dana untuk kegiatan yang berkaitan dengan palemahan serta bagaimana Konsep Tri Hita Karana diterapkan dalam Pengelolaan Keuangan Desa.

\section{Hasil dan Pembahasan}

\subsection{Pengelolaan Keuangan Desa di Desa Anturan}

Pengertian Keuangan Desa menurut UU Desa adalah semua hak dan kewajiban desa yang dapat dinilai dengan uang serta segala sesuatu berupa uang dan barang yang berhubungan dengan pelaksanaan hak dan kewajiban Desa. Hak dan kewajiban tersebut menimbulkan pendapatan, belanja, pembiayaan yang perlu diatur dalam pengelolaan keuangan desa yang baik. Siklus pengelolaan keuangan desa meliputi perencanaan, pelaksanaan, penatausahaan, pelaporan, dan pertanggungjawaban, dengan periodisasi 1 (satu) tahun anggaran, terhitung mulai tanggal 1 Januari sampai dengan 31 Desember. Gambaran rincian proses Siklus Pengelolaan Keuangan Desa adalah sebagai berikut:

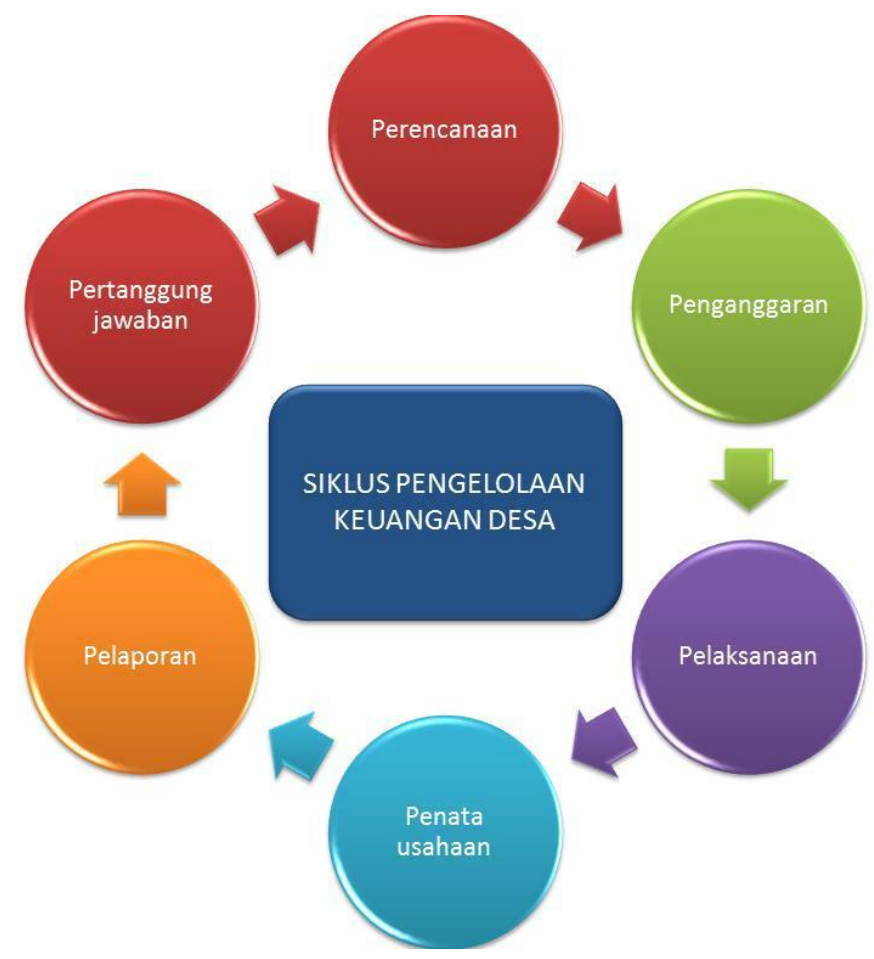

Gambar 2.1

Siklus Pengelolaan Keuangan Desa

Sumber Bahan Paparan Deputi Bidwas Penyelenggaraan Keuangan Daerah - BPKP "Akuntabilitas Pengelolaan Keuangan Desa" saat acara Rapat Kerja APPSI, Ambon 27 Februari 2015.

Setiap tahapan proses pengelolaan keuangan desa tersebut memiliki aturan-aturan yang harus dipahami dan dilaksanakan sesuai dengan batasan waktu yang telah ditentukan.

Untuk memahami pengelolaan keuangan desa secara utuh, berikut disajikan gambaran umum pengelolaan keuangan desa dikaitkan dengan pemerintah pusat/provinsi/kabupaten/kota, subjek pelaksananya di desa, struktur APB Desa, laporan dan lingkungan strategis berupa ketentuan yang mengaturnya. 


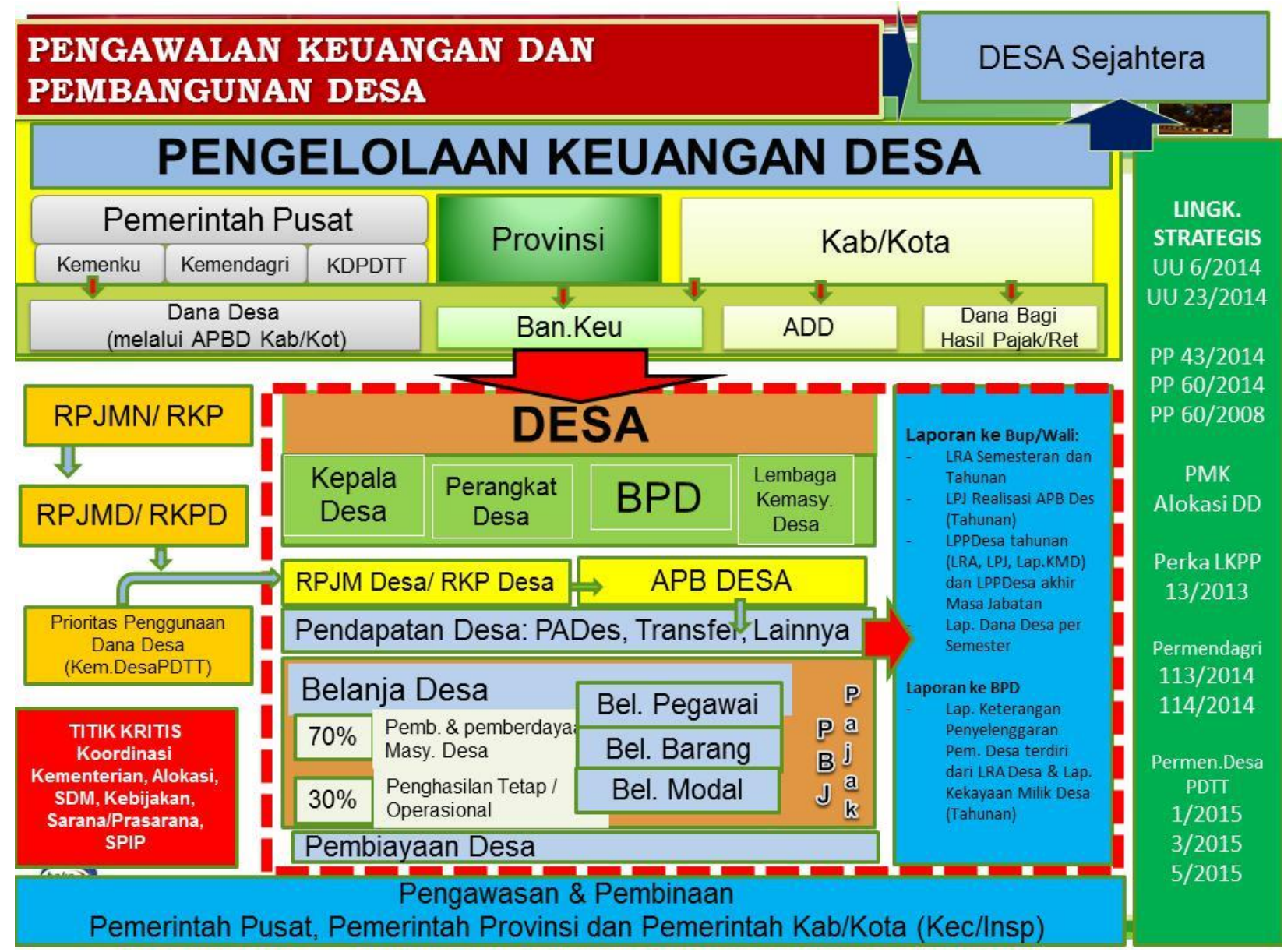

Gambar 2.2

\section{Gambaran Umum Pengelolaan Keuangan Desa}

Sumber: Bahan Paparan Deputi Bidwas Penyelenggaraan Keuangan Daerah - BPKP "Akuntabilitas Pengelolaan Keuangan Desa" saat acara Rapat Kerja APPSI, Ambon 27 Februari 2015.

Gambaran umum ini merupakan gambaran pengelolaan keuangan desa yang akan dijadikan dasar dalam kegiatan pengelolaan keuangan Desa di Desa Anturan yang berdasarkan pada konsep Tri Hita Karana.

\subsubsection{Perencanaan Keuangan Desa di Desa Anturan}




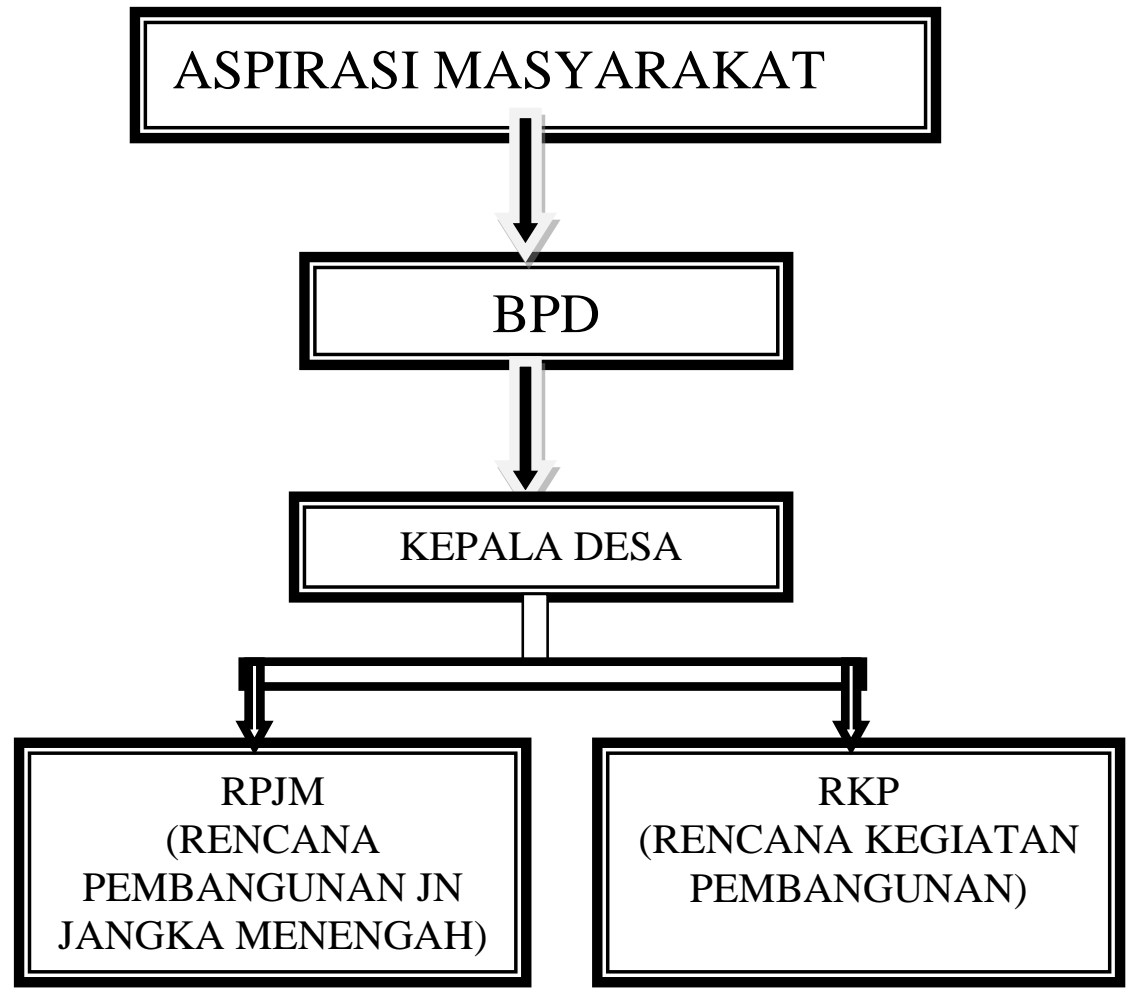

Gambar.2.3

Alur perencanaan pengelolaan APB di Desa Anturan

Pemerintah Desa menyusun perencanaan pembangunan desa sesuai dengan kewenangannya dengan mengacu pada perencanaan pembangunan kabupaten/kota. Perencanaan Pembangunan Desa meliputi RPJM Desa dan RKP Desa yang disusun secara berjangka dan ditetapkan dengan Peraturan Desa. Adapun sistem penyusunan yang dilakukan di Desa Anturan dalam melakukan Rencana Pembangunan Jangka Menengah Desa (RPJM Desa) untuk jangka waktu 6 (enam) tahun sedangkan Rencana Pembangunan Tahunan Desa atau yang disebut Rencana Kerja Pemerintah Desa (RKP Desa) untuk jangka waktu 1 (satu) tahun. RKP Desa merupakan penjabaran dari Rencana Pembangunan Jangka Menengah Desa. Perencanaan pembangunan desa disusun berdasarkan hasil kesepakatan dalam musyawarah desa yang pelaksanaannya paling lambat pada bulan Juni tahun anggaran berjalan.

a. Rencana Pembangunan Jangka Menengah Desa (RPJM Desa)

Dalam menyusun RPJM Desa, pemerintah desa wajib menyelenggarakan Musyawarah Perencanaan Pembangunan Desa (Musrenbangdes) secara partisipatif. Musrenbangdes diikuti oleh pemerintah desa, Badan Permusyawaratan Desa dan unsur masyarakat desa, yang terdiri atas tokoh adat, tokoh agama, tokoh masyarakat dan/atau tokoh pendidikan. RPJM Desa ditetapkan dalam jangka waktu paling lama $\mathbf{3}$ (tiga) bulan terhitung sejak tanggal pelantikan kepala desa.

b. Rencana Kerja Pemerintah Desa (RKP Desa)

RKP Desa disusun oleh Pemerintah Desa sesuai dengan informasi dari pemerintah daerah kabupaten/kota berkaitan dengan pagu indikatif desa dan rencana kegiatan pemerintah, pemerintah daerah provinsi, dan pemerintah daerah kabupaten/kota. RKP Desa mulai disusun oleh Pemerintah Desa pada bulan Juli tahun berjalan dan sudah harus ditetapkan paling lambat pada bulan September tahun anggaran berjalan. Rancangan RKP Desa paling sedikit berisi uraian sebagai berikut:

1) Evaluasi pelaksanaan RKP Desa tahun sebelumnya;

2) Prioritas program, kegiatan, dan anggaran desa yang dikelola oleh desa; 
3) Prioritas program, kegiatan, dan anggaran desa yang dikelola melalui kerja sama antar-desa dan pihak ketiga;

4) Rencana program, kegiatan, dan anggaran desa yang dikelola oleh desa sebagai kewenangan penugasan dari pemerintah, pemerintah daerah provinsi, dan pemerintah daerah kabupaten/kota;

5) Pelaksana kegiatan desa, yang terdiri atas unsur perangkat desa dan/atau unsur masyarakat desa

\subsubsection{Proses Penganggaran Keuangan Desa}

Setelah RKP Desa ditetapkan maka dilanjutkan proses penyusunan APB Desa. Rencana Kegiatan dan Rencana Anggaran Biaya yang telah ditetapkan dalam RKP Desa dijadikan pedoman dalam proses penganggarannya. Anggaran Pendapatan dan Belanja Desa (APB Desa) merupakan rencana anggaran keuangan tahunan pemerintah desa yang ditetapkan untuk menyelenggarakan program dan kegiatan yang menjadi kewenangan desa.

Proses Penyusunan APB Desa dimulai dengan urutan sebagai berikut:

a. Pelaksana Kegiatan menyampaian usulan anggaran kegiatan kepada Sekretaris Desa berdasarkan RKP Desa yang telah ditetapkann;

b. Sekretaris Desa menyusun rancangan Peraturan Desa tentang APB Desa (RAPB Desa) dan menyampaikan kepada Kepala Desa;

c. Kepala Desa selanjutnya menyampaikan kepada Badan Permusyawaratan Desa untuk dibahas dan disepakati bersama. Rancangan Peraturan Desa tentang APB Desa disepakati bersama paling lambat bulan Oktober tahun berjalan antara Kepala Desa dan BPD;

d. Rancangan Peraturan Desa tentang APB Desa yang telah disepakati bersama sebagaimana selanjutnya disampaikan oleh Kepala Desa kepada Bupati/Walikota melalui camat atau sebutan lain paling lambat 3 (tiga) hari sejak disepakati untuk dievaluasi;

e. Bupati/Walikota menetapkan hasil evaluasi Rancangan APB Desa paling lama 20 (dua puluh) hari kerja sejak diterimanya Rancangan Peraturan Desa tentang APB Desa. Dalam hal Bupati/Walikota tidak memberikan hasil evaluasi dalam batas waktu maka Peraturan Desa tersebut berlaku dengan sendirinya. Dalam hal Bupati/Walikota menyatakan hasil evaluasi Rancangan Peraturan Desa tentang APB Desa tidak sesuai dengan kepentingan umum dan peraturan perundang-undangan yang lebih tinggi Kepala Desa melakukan penyempurnaan paling lama 7 (tujuh) hari kerja terhitung sejak diterimanya hasil evaluasi. Apabila hasil evaluasi tidak ditindak lanjuti oleh Kepala Desa dan Kepala Desa tetap menetapkan Rancangan Peraturan Desa tentang APB Desa menjadi Peraturan Desa, Bupati/Walikota membatalkan Peraturan Desa dengan Keputusan Bupati/Walikota yang sekaligus menyatakan berlakunya pagu APB Desa tahun anggaran sebelumnya;

f. Peraturan Desa tentang APB Desa ditetapkan paling lambat tanggal 31 Desember tahun anggaran berjalan 
Flowchart dan jadwal waktu penyusunan APB Desa dapat dilihat dalam gambar berikut:

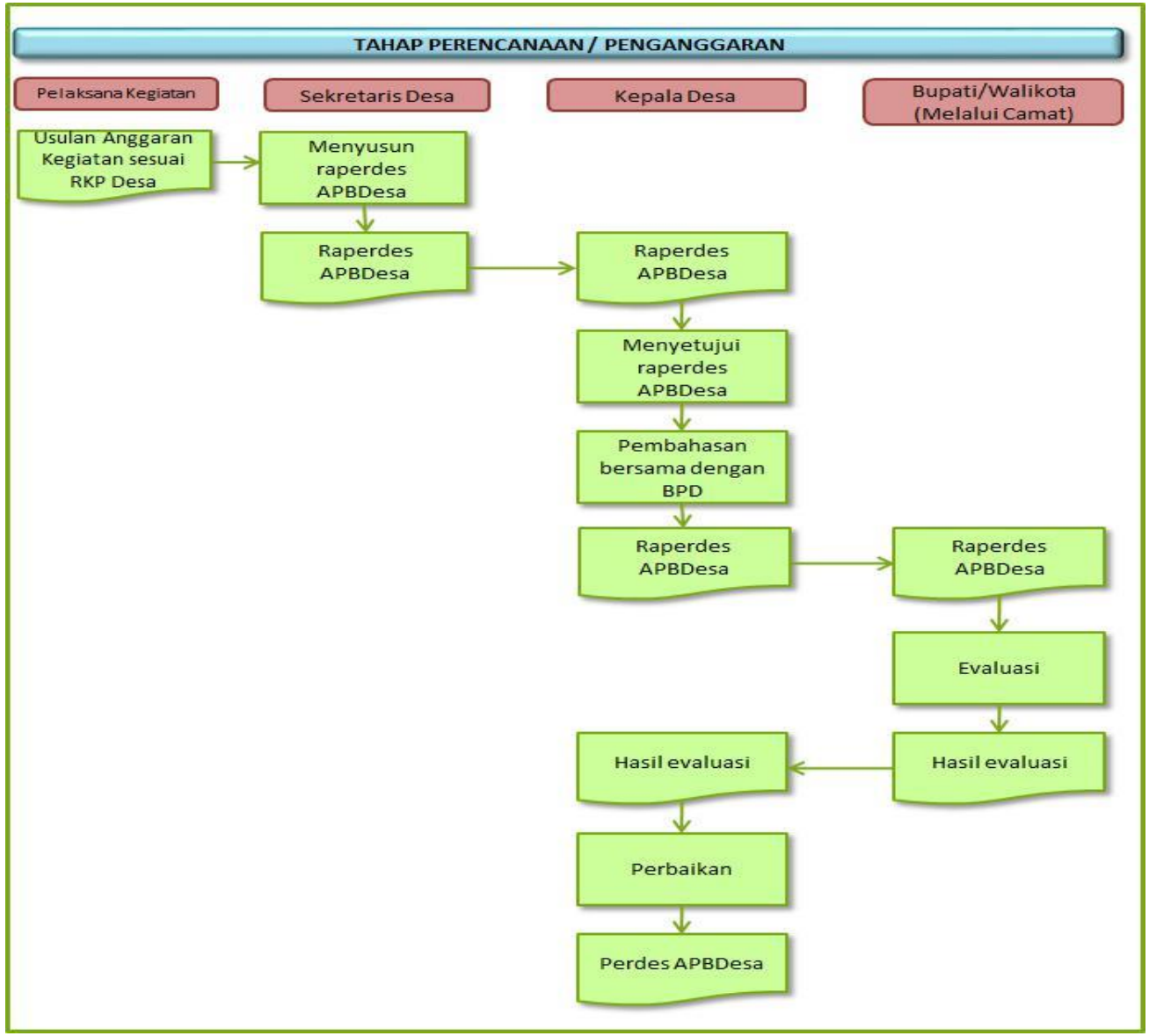

Gambar 2.4

Flowchart Penyusunan APB Desa di Desa Anturan

\subsubsection{Pelaksanaan APB Desa Anturan}

Pelaksanaan penerimaan pendapatan yaitu proses menerima dan mencatat pendapatan desa. Pendapatan desa yang bersifat Pendapatan Asli Desa berasal dari masyarakat dan lingkungan desa, sedangkan pendapatan transfer berasal dari pemerintah supra desa. Pihak yang terkait dalam proses penerimaan pendapatan adalah pemberi dana (Pemerintah Pusat/Prov/Kab/Kota, Masyarakat, Pihak ketiga), Penerima Dana (Bendahara Desa/Pelaksana Kegiatan/Kepala Dusun) dan bank.

Belanja Desa diprioritaskan untuk memenuhi kebutuhan pembangunan yang disepakati dalam Musyawarah Desa dan sesuai dengan prioritas Pemerintah baik pemerintah pusat maupun pemerintah provinsi/kabupaten/kota. Hal tersebut seluruhnya tertuang dalam RKP Desa yang pelaksanaannya akan diwujudkan melalui APB Desa.

Setelah APB Desa ditetapkan dalam bentuk Peraturan Desa, program dan kegiatan sebagaimana yang telah direncanakan baru dapat dilaksanakan. Hal ini dikecualikan untuk Belanja Pegawai yang bersifat mengikat dan operasional perkantoran yang diatur dalam Keputusan Kepala Desa.

\subsubsection{Penatausahaan Keuangan Desa}

Penatausahaan Keuangan Desa adalah kegiatan pencatatan yang khususnya dilakukan oleh Bendahara Desa. Bendahara Desa wajib melakukan pencatatan terhadap seluruh transaksi yang ada berupa penerimaan dan pengeluaran. Bendahara Desa melakukan pencatatan secara sistematis dan kronologis atas transaksi-transaksi keuangan yang terjadi. Penatausahaan keuangan desa yang dilakukan oleh Bendahara Desa 
dilakukan dengan cara sederhana, yaitu berupa PEMBUKUAN belum menggunakan jurnal akuntansi.

Penatausahaan baik penerimaan kas maupun pengeluaran kas, Bendahara Desa menggunakan:

1) Buku Kas Umum;

2) Buku Kas Pembantu Pajak; dan

3) Buku Bank.

Bendahara Desa melakukan pencatatan atas seluruh penerimaan dan pengeluaran dalam Buku Kas Umum untuk yang bersifat TUNAI. Sedangkan transaksi penerimaan dan pengeluaran yang melalui bank/transfer dicatat dalam Buku Bank. Buku Kas Pembantu Pajak digunakan oleh Bendahara Desa untuk mencatat penerimaan uang yang berasal dari pungutan pajak dan mencatat pengeluaran berupa penyetoran pajak ke kas Negara. Khusus untuk pendapatandan pembiayaan, terdapat buku pembantu berupa Buku Rincian Pendapatan dan Buku Rincian Pembiayaan.

\subsubsection{Pelaporan dan Pertanggungjawaban Keuangan Desa}

Dalam melaksanakan tugas, kewenangan, hak, dan kewajibannya dalam pengelolaan keuangan desa, kepala desa memiliki kewajiban untuk menyampaikan laporan. Laporan tersebut bersifat periodik semesteran dan tahunan, yang disampaikan ke Bupati/Walikota dan ada juga yang disampaikan ke BPD. Rincian laporan sebagai berikut:

1) Laporan kepada Bupati/Walikota (melalui camat):

2) Laporan Semesteran Realiasasi Pelaksanaan APB Desa;

3) Laporan Pertanggungjawaban Realisasi Pelaksanaan APB Desa kepada Bupati/Walikota setiap akhir tahun anggaran.

4) Laporan Realisasi Penggunaan Dana Desa

5) Laporan kepada Badan Permusyawaratan Desa (BPD)

6) Laporan Keterangan Pertanggungjawaban Realisasi Pelaksanaan APB Desa terdiri dari Pendapatan, Belanja, dan Pembiayaan

\section{Laporan Realisasi Pelaksanaan APB Desa di Desa Anturan}

Laporan Realiasasi Pelaksanaan APB Desa disampaikan kepada Bupati/Walikota melalui camat, terdiri dari:

a) Laporan Semester Pertama, disampaikan paling lambat pada akhir bulan Juli tahun berjalan;

b) Laporan Semester Akhir Tahun, disampaikan paling lambat pada akhir bulan Januari tahun berikutnya.

\section{Laporan Pertanggungjawaban Realisasi Pelaksanaan APB Desa di Desa Anturan}

Laporan Pertanggungjawaban Realisasi Pelaksanaan APB Desa Setiap Akhir Tahun Anggaran disampaikan kepada Bupati/Walikota melalui camat terdiri dari Pendapatan, Belanja, dan Pembiayaan yang telah ditetapkan dengan Peraturan Desa. Setelah Pemerintah Desa dan BPD telah sepakat terhadap Laporan Pertanggungjawaban Realisasi Pelaksanaan APB Desa dalam bentuk Peraturan Desa, maka Perdes ini disampaikan kepada Bupati/Walikota sebagai bagian tidak terpisahkan dari Laporan Penyelenggaraan Pemerintahan Desa. Laporan Pertanggungjawaban Realisasi Pelaksanaan APB Desa sebagaimana tercantum dalam pada pasal 41 Permendagri 113/2014, disampaikan paling lambat 1 (satu) bulan setelah tahun anggaran berkenaan.

\section{Laporan Realisasi Penggunaan Dana Desa}

Laporan Realisasi Penggunaan Dana Desa disampaikan kepada bupati/walikota setiap semester. Penyampaian laporan realisasi penggunaan Dana Desa dilakukan:

a) Untuk semester I paling lambat minggu keempat bulan Juli tahun anggaran berjalan.

b) Untuk semester II paling lambat minggu keempat bulan Januari tahun anggaran berikutnya. 
c) Berdasarkan Laporan Dana Desa dari desa-desa yang ada di wilayah kabupaten/kota, Bupati/Walikota menyampaikan Laporan Realisasi Penyaluran dan Konsolidasi Penggunaan Dana Desa kepada Menteri keuangan dengan tembusan menteri yang menangani desa, menteri teknis/pimpinan lembaga pemerintah nonkementerian terkait, dan gubernur paling lambat minggu keempat bulan Maret tahun anggaran berikutnya.

\section{Laporan Pertanggungjawaban Realisasi Pelaksanaan APB Desa di Desa Anturan}

Laporan Pertanggungjawaban Realisasi Pelaksanaan APB Desa merupakan laporan yang disampaikan secara periodik kepada BPD terhadap pelaksanaan APB Desa yang telah disepakati di awal tahun dalam bentuk Peraturan Desa.Laporan Pertanggungjawaban Realisasi Pelaksanaan APB Desa dilampiri:

a) Format Laporan Pertanggungjawaban Realisasi Pelaksanaan APB Desa Tahun Anggaran berkenaan;

b) Format Laporan Kekayaan Milik Desa per 31 Desember Tahun Anggaran berkenaan; dan

c) Format Laporan Program Pemerintah dan Pemerintah Daerah yang Masuk ke Desa.

Rancangan Peraturan Desa tentang Pertanggungjawaban Realiasi Pelaksanaan APB Desa tidak dilakukan evaluasi sebagaimana proses peraturan desa untuk penetapan APB Desa. Hal ini didasarkan pada Permendagri Nomor 111 Tahun 2014 tentang Pedoman Teknis Peraturan di Desa pada pasal 14 dimana dinyatakan hanya 4 (empat) jenis Rancangan Peraturan Desa yang telah dibahas dan disepakati oleh Kepala Desa dan BPD yang dilakukan evaluasi oleh Bupati/Walikota melalui camat yaitu tentang:

a) APB Desa,

b) Pungutan,

c) Tata Ruang, dan;

d) Organisasi Pemerintah Desa

\subsection{Alokasi Dana Untuk Kegiatan Yang Berkaitan Dengan Perahyangan}

Parahyangan berasal dari kata hyang yang artinya Tuhan. Parahyangan berarti ketuhanan atau hal-hal yang berkaitan dengan keagamaan dalam rangka memuja ida sang hyang widhi wasa. Dalam arti yang sempit parahyangan berarti tempat suci untuk memuja tuhan, dalam hal ini parahyangan dapat dilihat dibeberapa tingkat dibali yaitu : parahyangan untuk ditingkat daerah berupa kahyangan jagat, di tingkat desa adat berupa kahyangan desa atau kahyangan tiga dan ditingkat keluarga berupa merajan atau sanggah. Dimana Perahyangan itu sendiri merupakan hubungan yang harmonis antara manusia dengan Tuhan, dalam hal ini manusia diharapkan memilki kedekatan batin dengan Tuhan, setiap aktifitas didasari oleh semangat pengabdian pada Tuhan. Manusia menyadari jati dirinya sebagai atman atau mahluk spiritual yang harus selalu berhubungan dengan sumbernya yaitu tuhan. (Anonym:2016).

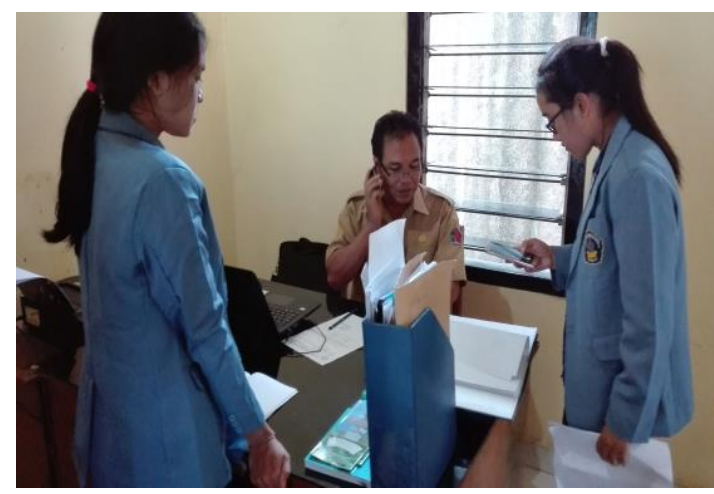

Menurut sekertaris desa Anturan Bapak I Ketut Damayasa menyatakan bahwa "Berdasarkan konsep parahyangan dalam Tri Hita Karana ,pengalokasian keuangan desa di tahun 2016 dari keseluruhan anggaran yang diberikan pemerintah kepada pengelola keuangan desa sebesar 15\% dialokasikan untuk kegiatan yang berhubungan dengan 
parahyangan (hubungan manusia dengan Tuhan). Kegiatan yang dimaksud seperti pembinaan pemangku, kegiatan fasilitas upacara keagamaan, dan perbaikan tempat suci di desa anturan". Adapun rincian pengalokasian dana untuk kegiatan keagamaan tersebut adalah sebagai berikut:

1. Banten dan upacara utk Desa Pakraman Anturan

2. Upacara Ngusaba Subak Anturan

3. Upacara Ngusaba Subak Celuk Buluh

4. Pembangunan Balai Pesandekan Jaba sisi Pura Dewa Gede Patih

5. Rehab Wantilan Jaba Sisi Pura Dewa Gede Patih

6. Pembuatan Terob Pura Subak Anturan.

7. Pembangunan Balai Paruman Subak Celuk Buluh

8. Ukir Balai Kulkul Subak Abian Catur Kerthi

9. Pemasangan Pagar sebelah utara Pura Subak Abian Catur Kerthi

(Terlampir)

Dengan demikian, kegiatan-kegiatan yang telah dilaksanakan yang berkaitan dengan prahyangan dapat menfasilitasi masyarakat untuk melaksanakan persembhyangan yang bertujuan untuk mendekatkan diri kepada Tuhan Yang Maha Esa.

\subsection{Alokasi Dana Untuk Kegiatan Yang Berkaitan Dengan Pawongan}

Konsep pawongan dalam Tri Hita Karana merupakan keharmonisan hubungan manusia dengan manusia. Konsep pawongan memandang kedudukan manusia sama dihadapan Tuhan. Semua manusia mempunyai hak untuk mendapatkan kesejahtraan hidup (Jagadita) dan mencapai penyatuan diri dengan Tuhan (moksa). Jiwa/roh/atman semua mahluk pada dasarnya sama, tetapi tingkat kebesannya atau kemuliannya bergantung pada karma mahluk hidup yang ditempati (mewadahi). Manusia lahir (bereinkarnasi) berulangulang sebagai kesempatan untuk memperbaiki karmanya untuk dapat mencapai tujuan akhir yakni bersatu dengan sang Pencipta (Tuhan). (Anonym:2014)

Menurut sekertaris desa Anturan Bapak I Ketut Damayasa menyatakan bahwa "Aktifitas hubungan antar manusia baik secara langsung maupun tidak langsung merupakan satu bentuk wahana berkarma. Kesadaran terhadap perlunya hubungan harmoni antar manusia berbagai wadah sosial atau kesepakatan masyarakat berkembang di Bali antara lain desa pakraman, dadia, sekeha subak, awig-awig desa atau sekeha yang pada umumnya dapat disesuaikan dengan perkembangan jaman. Banyak bentuk kegiatan sosial di Desa Anturan seperti penyelenggaraan hampir semua upacara yadnya, kesenian, dan berbagai paruman. Bebera fasilitas yang mendukung aktivitas sosila di desa Anturan antara lain keberadaan tempat pertemuan krama/warga dan berbagai kegiatan yang dibuat oleh pengurus desa setempat untuk semakin memperkuat keharmonisan antar warga setempat (seperti wantilan desa, bale dadia, dan bale subak) dengan kegiatan seperti sangkep (pertemuan anggota)".

Dilihat dari laporan realisasi penggunaan alokasi dana desa di desa Anturan terlihat dengan jelas pengalokasian dana tersebuiat dipergunakan untuk mensejahtrkan masyarakatnya kegiatan kegiatan yang telah dilaksanakan seperti:

1. Kegiatan operasional prebekel dalam rangka kegiatan social masyarakat

2. Kegiatan rapat-rapat koordinasi

3. Kegiatan hari besar nasional

4. Kegiatan penyusunan praturan desa tentang pungutan

5. Kegiatan penyusunan peraturan desa tentang BUMDes

6. Kegiatan faslitas dan pengembangan sistem administrasi dan informasi desa

7. Kegiatan fasilitas dan pembangunan TPST

8. Kegiatan gerak sehat untuk lanjut usia

9. Kegiatan penyelenggaran pencegahan dan pemberantasan penyakit menular dan wabah

10.Kegiatan pembinaan lembaga adat

11.Kegiatan pembinaan lembaga LPM

12.Kegiatan pembinaan lembaga PKK

13.Kegiatan pembinaan gong anak-anak 
(terlampir)

Kegiatan kegiatan yang dilaksanakan oleh pengurus desa tersebut dilaksanakan untuk kepentingan msyarakat sekitar dan menjalin keharmonisan antar warga. Selain itu pengelolaan dana desa yang baik dapat memberikan kesejahtrahan bagi warga desa anturan.

\subsection{Alokasi Dana Yang Berkaitan dengan Palemahan}

Palemahan merupakan konsep hubungan manusia dengan alam, dimana konsep ini manusia diharapkan memiliki tanggung jawab pada alam dalam mengelola alam tersebut. Manusia tidak hanya memanfaat alam tanpa memperhatikan kelestariannya. Manusia dengan demikian sangat tergantung kepada lingkungannya. Oleh karena itu manusia harus selalu memperhatikan situasi dan kondisi lingkungannya. Lingkungan yang ditata dengan rapi dan bersih akan menciptakan keindahan. Keindahan lingkungan dapat menimbulkkan rasa tenteram dalam diri manusia. (Anonym:2014)

Menurut sekertaris desa Anturan Bapak I Ketut Damayasa menyatakan bahwa " Berdasarkan konsep palemahan dalam Tri Hita Karana tersebut, bahwa alokasi dana yang berkaitan dengan pelamahan yang ada di desa Anturan sebesar $70 \%$ yang digunakan untuk kepentingan infrastruktur yang diperlukan untuk kebutuhan di desa Anturan",seperti:

1. Kegiatan pemeliharaan kantor desa

2. Kegiatan pemeliharaan sarana dan prasarana kantor Desa

3. Pemeliharaan balai banjar

4. Kegiatan pembinaan dan peningkatan kapasitas Limas (Lingkungan Masyarakat)

5. Kegiatan fasilitas dan pembangunan TPST

6. Kegiatan penyelenggaraan pencegahan dan pembrantasan penyakit menular dan wabah (Terlampir)

Dengan demikian, kegiatan-kegiatan yang telah dilaksanakan yang berkaitan dengan Palemahan dapat membantu dan mensejahterakan masyarakat yang ada di desa Anturan.

\subsection{Konsep Tri Hita Karana diterapkan dalam Pengelolaan Keuangan Desa}

Dari observasi yang kami lakukan, maka dapat di simpulkn bahwa di Desa Anturan dalam pengelolaan keuanganya telah berdasarkan pada konsep Tri Hita Karana, yaitu dilihat dari pengalokasian dana keuangan,dimana $15 \%$ dana dialokasikan untuk kegiatan pemerdayaan masyarakat hal ini tentu mencermikan konsep Tri Hita Karana yang berkaitan dengan konsep pawongan,dimana kita sebgai manusia harus menjaga hubungan antara manusia sehingga tercemin kedamaian,yang tentu dapat mempengaruhi tingkat kualitas organisasi yang dijalankan sehingga dapat mencapai tujuan sesuai yang telah direncanakan untuk kesejahteraan masyarakat., selanjutnya dana tersebut di alokasi sebesar 15\% berkaitan dengan pembangunan tempat ibadah maupun pelaksanan upacara yadnya.Pengalokasian keuangan desa dalam konsep prahyangan tentu memiliki hubungan yang sangat erat misalkan saja dalam mejalankan organisasi tidak didasarkan keyakinan kepada Ida Sang Hyang Widhi , tentu tidak dapat berjalan secara lancar mengingat setiap hal harus di dasarkan pada keyakinan terhadap tuhan sehingga dapat menjalan organisasi berdasrkan asas darma. Kemudian 70\%nya digunakan untuk infrastruktur desa yang berhubungan dengan lingkungan antara, berdasarkan konsep palemahann lingkungan , tentu manusia dalam menjalankan organisasi harus memperhatikan lingkungan, karena lingkunagan akan memberi manfaat jika manusia dapat menjaga dan memperhatikan lingkungan dengan cara melestarikan lingkungan

Yang dapat didanai oleh dana desa yaitu aset-aset milik desa. Hubungan dana desa dengan kelestarian lingkungan contohnya pengelolaan sampah dan pembangunan desa. Adapun Dana yang diperoleh dari pemerintah pusat pada tahun 2016 sebesar Rp 623.819.238,73 dan Dana tersebut tidak boleh dipergunakan untuk kesejahteraan karyawan.

Cara pengelolaan dana desa di setip desa berbeda-beda biasanya pengelolaan dana tersebut dilihat dari jumlah penduduk, luas daerah, dan tingkat kemiskian di desa tersebut. APBDES dibuat untuk merencanakan penganggaran dana desa. APEBEDES terdir dari: 
1. Dana desa

2. Alokasi dana desa

3. Hasil pajak dari distribusi

4. Pendapatan asli desa

Dalam pembuatan APEBEDES desa mengalokasikan dana dengan membuat rancangan bersama BPD, setelah rencana tersebut disetujui kemudian dimasukan ke APBD.

Apabila dana rancangan yang diberikan oleh pemerintah pusat terdapat sisa atau yang dimaksud dengan sisa anggaran tahun lalu, maka dana tersebut akan dipergunakan untuk rancangan tahun depan misalnya kelebihan dana di tahun 2016 dipergunakan untuk rancangan di tahun 2017. Apabila terdapat kekurangan dana maka akan diadakan perubahan tiap tahunnya dimana anggaran tersebut disesuaikan lagi.

Terdapat 5 staf yang berperan untuk mengelola dana desa misanya bagian pembangunan, mereka terfokus di dalam bagian pembangunan saja dimana dana desa yang diberikan pemerintah pusat itu direalisasikan secara bertahap, misalkan pada tahap pertama diberikan dana sebesar $60 \%$ dan sisanya akan diberikan apabila dana $60 \%$ itu telah direalisasikan.

\section{Simpulan dan Saran}

Dari penelitian diatas dapat disimpulkan bahwa terdapat pengaruh Tri Hita Karana dalam pengelolaan keuangan desa di desa Anturan dimana dibuktikan dengan kegiatankegiatan yang telah dilaksanakan oleh pengurus desa yang mencerminkan hubungan manusia dengan Tuhan (prahyangan), manusia dengan manusia (pawongan), manusia dengan lingkungan (palemahan), seperti kegiatan fasilitasi pelaksanaan upacara keagamaan,kegiatan oprasional perbekel dalam rangka kegiatan sosial masyarakat, kegiatan pemeliharaan balai banjar. Adapun alokasi dana yang berhubungan dengan prahayangan yaitu $15 \%$, palemahan $70 \%$ dan pawongan $15 \%$.

Berdasarkan kesimpulan diatas, maka penulis dapat memberikan saran-saran sebagai berikut:

1. Diharapkan Pengelolaan Keuangan di Desa Anturan dapat menjadi dasar penerapan konsep Tri Hita Karana yang berkaitan dengan, Prahyangan, Pawongan dan Palemahan. Dimana Tri Hita Karana itu sendiri merupakan kearifan lokal (lokal wisdom) yang sudah menjadi kepribadian budaya karena mampu mengakomodasikan dan mengintegrasikan unsur-unsur budaya luar ke dalam kebudayaan asli sekaligus menjadi bingkai tatanan kehidupan masyarakat Bali dengan berbagai sektor.

2. Penerapan Konsep Tri Hita Karana dalam pengelolaan keuangan desa di desa Anturan, diharapkan dapat mensejahterakan masyarakat di desa tersebut.

\section{DAFTAR PUSTAKA}

Anonym. 2016.Tri Hita Karana Diunduh tanggal 8 Desember 2016, https://id.M. Wikipedia.Org/wiki/Tri_Hita_Karana.

Anonym. 2014. Implementasi Tri Hita Karana. Diunduh tanggal 8 Desember 2016, http://blogspot.co.id/2014/11/implementasi-tri- hita- karana-dalam.html

Anonym. 2015. Petunjuk Pelaksanaan Bimbingan \& Konsultasi pengelolaan Keuangan Desa. jakarta : Deputi Bidang Pengawasan Penyelenggaraan Keuangan Daerah 